$\mathbb{T}$ periodica polytechnica

\author{
Social and Management Sciences \\ 20/2 (2012) 71 79 \\ doi: 10.3311/pp.so.2012-2.02 \\ web: http://www.pp.bme.hu/so \\ (c) Periodica Polytechnica 2012
}

RESEARCH ARTICLE

\section{A review of customer satisfaction towards service quality of banking sector}

\author{
Amudha Ramachandran / Vijayabanu Chidambaram
}

Received 2012-01-07

\begin{abstract}
Service process performance of an organization should be measured continuously to achieve competitive advantage and this is possible through providing excellent service by any organization. The quality of the products or the quality of customer service determines the degree of customer satisfaction. The customer satisfaction not only means, satisfying the customers but also customer retention in case of service failure. The organization should solve the complaints through various service recovery strategies. It is mandatory to identify the impact of service failure and customer feedback for the survival, success and prosperity of an organization. The real victory of an organization is based on the degree of loyalty of the customers. This paper attempts to summarize the results of literature review on customer satisfaction towards the services of a bank from five different perspectives namely, service encounters, waiting time of the customer to get the service, role of intermediaries, quality of service provided and customer complaints towards the bank. Attraction, retention and enhancement of the customer relationship are essential to maintain, delighted and committed customers, who form the basis for the sustainable competitive position of the bank. This study can also be extended to tourism and hospitality, insurance companies, hospitals, transport corporations, railways, airlines, telecommunications, libraries and other service sectors to assess the degree of quality of service offered by them.
\end{abstract}

\section{Keywords}

Customer satisfaction · service encounters - intermediaries . quality of service $\cdot$ waiting time and customer complaints.

\section{Acknowledgement}

The authors would like to thank anonymous referees, for their thoughtful comments and helpful suggestions for the improvement of the manuscript.

\section{Amudha Ramachandran}

Vijayabanu Chidambaram

School of Management, SASTRA University, Thirumalaisamudrum, Thanjavur, Tamil Nadu, India

\section{Introduction}

In the present scenario, successful corporations gain competitive advantage through increased efficiency, high quality of service and improved customer relationship. Customers get information about the organization through customer advocacy. Creating and maintaining customer loyalty have become important in current service markets. In financial service industry, maintaining superior service quality is considered critical in achieving customer satisfaction, value creation and growth. The ability to understand the needs of the consumer with respect to the product or service is vital for measuring the level of consumer satisfaction.

Every business organization aims to satisfy its customers to a great extent, as the customer satisfaction lays foundation for the success of the business. The measurement of customer satisfaction has become mandatory in any organization. The quality of the products or the quality of customer service determines the degree of customer satisfaction. The customer satisfaction not only means, satisfying the customers but also customer retention in case of service failure. The organization should solve the complaints through various service recovery strategies. It is mandatory to identify the impact of service failure and customer feedback for the survival, success and prosperity of an organization. The real victory of an organization is based on the degree of loyalty of the customers. The measurement of customer satisfaction is intricate because most of the customers do not believe in the act of complaining as they feel it to be a waste of time and effort. Some of the customers may indulge in negative word-of-mouth, which will have a severe impact on the turnover of the organization. To avoid the negative impact on the revenue, every organization must collect feedback from its own customers. They should study and analyze the existing system of customer service and implement continuous improvement strategies by enhancing the quality of the service.

In the modern competitive world, service process performance is the most important to achieve competitive advantage. Tamas Jonas and Janos Kovesi (2010) [69] stated that understanding the customers' voice is a key contributor to success of any organization that provides services. Customer sovereignty is 
the key concept in marketing and it always assumed that the customer satisfaction is the crucial factor in determining the longrun prosperity of the business. K. Szabó [34] says that by the 1990's the technological development becomes able to meet the users' requirements again. For today it is possible to create standardized (or completely integrated) systems, which are ready to ensure the data processing on a higher level. In the life of the banks it means the centralization of knowledge centers which register customer information.

A. Parasuraman [47] suggests that the broadening the scope of marketing is to include the delivery of customer service as an integral component and demonstrates that a judicious blending of conventional marketing and superior customer service is the best recipe for sustained market success. A. T. Allred, H. L. Addams [7] have analyzed service quality from the view of access, courtesy, communication, credibility, security, empathy, tangibles, basic service, fairness, fixing mistakes and guarantees and have concluded that majority of the respondents have stopped using a financial service provider because of poor service performance.

V. A. Zeithaml, A. Parasuraman and A. Malhotra, [73] stated that to deliver superior service quality, managers of companies with Web presences must first understand how customers perceive and evaluate online customer service. A. P. Gaudet [1] suggested that technology satisfaction does drive overall customer satisfaction and that, in turn, overall customer satisfaction does drive loyalty. S. Byun [13] revealed that consumers' value was a good predictor of behavioral intention to use the technology while the value was mainly determined by perceived benefit rather than perceived risk. J. L. Heskett [29] suggested that while customer satisfaction and loyalty provide a foundation for high levels of customer lifetime value, they support a range of customer behaviours with widely varying values, characterized by mere loyalty (repeat purchase), commitment (willingness to refer others to a product or service), apostle-like behaviour (willingness to convince others to use a product or service), and ownership (willingness to recommend product or service improvements).

T. Rungting, [72] says that expectations and perceived service quality strongly influence customers' emotions; emotions have a strong impact on the perception of service experience and customer satisfaction; and service experience mediates the effects of expectations, service quality, and emotions on customer satisfaction. Vimi and Mohd (2008) [74] undertook a study of the determinants of performance in the Indian retail banking industry based on perception of customer satisfaction and stated that customer satisfaction is linked with performance of the banks. Bargal and Sharma [9] analysed the role of service marketing in banking sector. The identified important service factors in the banking sector are diversified services, flexible business transaction hours, accessibility of bank location, installation of web system, professional training to the employees, customers' complaint system and performance based appraisal system to enrich their services to their customers. S. D. Young [76] aimed at the establishment of a quantifiable connection linking customer loyalty to financial performance. The loyalty index used is a composite of four factors (use again, recommend to others, exceeding expectations, and satisfaction). M. A. Cowgill [17] identified four drivers of client satisfaction - financial, learning and growth of support staff, internal business processes, and client needs - to which sales people in the financial services industry (financial advisors) might pay attention in order to have satisfied clients.

The atmosphere in which the financial institutions operate has altered in recent years. With the increased competition, global market, growing product portfolio and diminishing margins, banking customers have also changed in recent years. Modern customers require flexibility in hours of operation, greater convenience, customization, transparency, accessibility and control. Competition and cost to attract the new customers and the expenses spent for it are heavy. Customer defection rates are higher than ever because of increased market competition. With so many different financial institutions to choose from consumers can now demand better quality services and more customized products from their banks. Thus, the study of customer satisfaction towards the quality of service of banking sector is the need of the hour.

This paper attempts to summarize the results of literature review on customer satisfaction towards the services of a bank from five different perspectives namely, service encounters, waiting time of the customer to get the service, role of intermediaries, quality of service provided by the bank and customer complaints towards the bank.

\section{Service encounters}

A service encounter is the time taken by the customer to interact with the service. It includes face-to-face, telephone communications, automated systems, e-mail and the like. This is the first stage where the customers judge the quality of service provided to them. Service encounters are otherwise called as servicescapes which means a physical environment in which the service is delivered and where the interaction between the customer and provider takes place.

Every encounter is a chance for the firm to satisfy the customer, to strengthen the value of its products, and to sell the customer on the benefits of a long-term relationship. Gummesson [26] describes service encounter as an interaction between a company's contact personnel and customers. Surprenant \& Solomon [68] describe it as the time-frame during which a customer directly interacts with the service provider. Czepiel [18] considered service encounter as a critical determinant of the customer's satisfaction with the service. In a business-to-business context the personal contacts are considered especially important for the relationships with customers. There is also a need to know all about the individual episodes that occur between companies in order to understand completely what happens be- 
tween them. Service environment is a silent salesman and it communicates service quality attributes, creates the service experience and forms customer expectations. P. A. Spirou [67] explored the determinants of service encounter satisfaction within a co-orientation framework that captures the interdependence of provider and client perceptions. The relationship between the set of variables consisting of client risk perception, service complexity, task communication, congruency and satisfaction were tested using responses from client-provider interactions in service business settings. A. C. Soteriou [66] states that delivering high quality service during the service encounter is considered as central to competitive advantage for any service organization. However, controlling the costs is a major challenge for service managers while achieving high quality.

Because of the intangibility, inseparability and heterogenity of services, the service encounter is critical to customer satisfaction and evaluation. Fisk [24] say that service encounters or experiences can be considered as moments of truth. M. J. Bitner [39] states that service environments, otherwise called as servicescapes relate to the style and appearance of the physical surroundings and other experiential elements encountered by customers at service delivery sites.

Customer satisfaction towards service encounter is transaction-specific. Shankar [62] say that service encounter satisfaction is related to overall customer satisfaction and overall satisfaction is driven by satisfaction from a series of service encounters. It is important, however, to recognize them as distinct constructs because of the factors influencing them may be different. Overall customer satisfaction is relationshipspecific. Bitner and Hubbert [38] and Oliver [45] reveal that the cumulative effect of a set of discrete service encounters or transactions with the service provider over a period of time influences customer satisfaction.

Designing a service environment is an art that takes considerable time and effort and can be expensive to execute. Once designed and built, service environments are not always easy to change. Schijns [55] suggests that customer satisfaction is necessary, but insufficient condition for customer loyalty. Service encounter immediately has an impact on customer satisfaction and also shape longer-term factors like intention to return, likelihood of communicating positively about the service and customer loyalty. Morgan and Hunt [52] say that trust exists "when one party has confidence in an exchange partner's reliability and integrity". Dwyer [51]; Morgan and Hunt [52]; Odekerken-Schroder [44]; Schijns [56] suggested that trust positively affects commitment and Berry says that trust is the basis for loyalty. Based on a company's reputation one could decide to do business and start a relationship with that company. The reputation of a potential new partner reduces the perceived risk of making the wrong decision and facilitates the change to the new partner. From this perspective, the reputation of a company lowers the entrance barriers for potential customers.

The service encounters of a bank include the type of en- counter used (face-to-face, telephone communications, e-mail and the like), the number of contacts made by the customers with the bank, the waiting time of the customers to communicate with the intermediaries, the time taken to communicate and the time taken by the intermediaries to fix the problem after the call, the number of times the call is made for the correction of the problem and the reasons the customers think fit for calling the intermediaries to call more than once. The level of satisfaction and dissatisfaction and the reasons for the same form the basis for the measurement of effectiveness of service encounters existing in the bank.

\section{Waiting time}

Waiting is frustrating because one has to do many things during that time. In a business, a customer hates waiting. To try to overcome this, an organization must properly design the service to minimize the waiting time which is practically difficult. The waiting time of the customers at the time of obtaining service has a major impact on their behaviour. Every company must implement a waiting line strategy to satisfy their customers.

N. Kallo and T. Koltai [43] studied the express lines generally used in supermarkets where many service facilities are located and each has its own separate waiting line. They have analysed with the help of two analytical models, one consisting many service facilities with one common waiting line and another containing many independent queuing systems in which there is one service facility with its own separate queue. They also state that in time-based competition environment, one of the main objectives of service managers is reducing customers' wait and the number of waiting customers can have significant effect on customer decisions. Increasing the capacity by adding more tellers is one of the strategies used to reduce the wait times in a bank. But, this can be done only when the customer satisfaction is balanced with cost considerations. The bank managers should also consider the redesigning of queuing system, redesign the process to shorten the time of each transaction and manage the consumer's behaviour and their perceptions of wait. Queue configurations refer to the number of queues, their locations, their spatial requirement and their effect on customer behaviour. Therefore, when queues become necessary, the service provider should decide how to configure the queue. $\mathrm{R}$. C. Larson [50] states that queueing environment and feedback regarding the likely magnitude of the delay can also influence customer attitudes and ultimately, in many instances, a firm's market share. B. G. C. Dellaert and B. E. Kahn [10] state that waiting for websites to load endangers negative affect among customers, but provided there is no uncertainty; consumers are able to separate the waiting experience from their retrospective evaluation of the site.

Sasser [54] provide good examples of both managing the perception and the expectation of waiting times. For the former, they offer an example of the well-known hotel group that received complaints from guests about excessive waiting times 
for elevators. After an analysis of how elevator service might be improved, it was suggested that mirrors be installed near where guests waited for elevators. The natural tendency of people to check their personal appearance substantially reduced complaints, although the actual wait for the elevators was unchanged. As an illustration of how expectations can be explicitly managed, they note that some restaurants follow the practice of promising guests a waiting time in excess of the expected time. If people are willing to agree to wait this length of time, they are quite pleased earlier, thus starting the meal with a more positive feeling.

A. Rafaeli, G. Barron and K. Haber [6] have found that the way in which waiting area is structured can produce feelings of injustice and unfairness in customers. Customers who waited in parallel lines to multiple servers reported significantly higher agitation and greater dissatisfaction with the fairness of service delivery process than did customers who waited in a single (snake) to access multiple servers, even though both groups of customers waited an identical amount of time and are involved in completely fair service process. The information regarding the relative position in the queue, length of waiting time, upcoming services and reason for waiting time will be useful for customers, as it allows them to take decisions about whether they can afford to take the time to wait now or should come back later. It also allows them to plan the use of their time while waiting. M. K. Hui and D. K. Tse [42] suggested that it may be more positive to let people know how their place in line is changing than to let them know how much time remains before they will be served. They conclude that people prefer to see or sense that the line is moving rather than to watch the clock.

J. R. Chernow [30] state that the travellers in public transportation use perceive time spent waiting for a bus or train as passing one and a half to seven times more slowly than the time spent traveling in the vehicle. G. Tom and S. Lucey [25] conclude that customer satisfaction/dissatisfaction is dependent not only on the customer identification of the causes as well as the stability and control of the causes. M. M. Davis, J. Heineke [37] state that the experience of waiting for service is often the first direct interaction between customers and most service delivery processes. In their study of satisfaction with waiting for service in a fast food environment, they demonstrate that actual waiting time, perceived waiting time and the disconfirmation between expected waiting time and perceived waiting time are all related to satisfaction with the waiting experience. They also conclude that for the customers who are concerned about time, the perception of the time spent waiting is a better predictor of satisfaction than the actual waiting time.

J. Chebat [14] says that waiting involves both emotions and cognition, in particular attribution of the cause for waiting. Mood affects some dimensions of service quality, those related to the personnel in contact; attribution affects the relational dimensions of service quality (personnel's empathy and assurance); mood does not affect the attribution process. Service quality is assessed not only in terms of what consumers receive at the end of the service delivery process but also in terms of the process itself.

M. K. Hui, M. V. Thakor and R. Gill [41] confirm from their study that the nature of the delay, in terms of whether it constitutes a threat to the successful completion of a task or not, moderates the impact of service stage on consumers' reactions to the wait. A. B. C. Diaz and F. J. M. Ruiz [5] say that people do not like wasting their time on unproductive activities any more than they like wasting money. Customer dissatisfaction with delays in receiving service can often stimulate strong emotions, including anger.

D.Soman, and R.Zhou [22] proposed that when people are told ahead of time to evaluate the length of a time period (prospective judgment), more events occurring during this period makes the period seem shorter. On the other hand, when people are asked about the length of the time period only after having experienced it (retrospective judgments), the more events, the longer the time period appears. A. Pruyn and A. Smidts [2] state that waiting appears to influence satisfaction quite strongly. The adverse effects of waiting can be soothed more effectively by improving the attractiveness of the waiting environment than by shortening the objective waiting time. D.Jillian and R.Jennifer [19] conclude that the successful management of waiting brings rewards to both the customer and the service provider.

\section{Role of intermediaries}

Every bank should position its intermediaries in such a way to meet the needs of the customers in a more responsive manner. This customer-intermediary relationship determines the quality of service provided which ultimately relates to customer satisfaction. Each customer should be personally attended; queries should be answered, as he is the valuable asset to the bank and future investment. When he is satisfied with the behaviour of the intermediaries, he will pass a positive word-of-mouth to his friends and relatives. S. Toelle [71] states that both employee performance and reliability have indirect effect on loyalty, mediated by customer value and satisfaction. S. W. Kelley[32] examined the effect of the level of organizational socialization achieved by service employees and customers upon customer perceptions of service quality. They indicated that employee and customer organizational socialization are positively related to service quality. Customer measures of organizational climate, customer orientation, motivational direction, organizational commitment, and satisfaction were positively related to service quality. Employee job satisfaction is directly related to customer perceptions of service quality. Finally, employee and customer organizational commitment is positively associated with satisfaction.

Schneider [60] is the first author to develop a framework for the study of people's basic overall perceptions about organizations and he has analyzed the perception of the organizational 
climate from the customer's viewpoint. The climate is defined as the added perception of customers about the firm they do business with. Later on, Parkington \& Schneider [48] Schneider \& Bowen [57, 58] have shown that when employees in their view have a different service orientation from the orientation adopted by the management, the former suffer from low levels of satisfaction, a strong intention to leave their jobs, high levels of frustration and the sensation that customers have a poor opinion of the service quality provided by the firm. In turn, Schneider [59] suggested that customers, attitudes towards service quality are strongly related to the employees' view about the service received by customers.

Brown \& Swartz [12] state that when a service is provided, the personal relationship established between employees and customers will be extremely important for determining the service quality. Therefore, employees' perceptions of the specific service-climate features strongly relate to the customers' perceptions about several features of that service climate and attitudes towards service. In turn, the perception of the quality offered by the organization on the part of the employee has an impact on the real quality offered. Hence, according to the sociocognitive theories developed by Bandura [8], Shea \& Howell [63] say that employees' behaviour is affected by the view of their own capacities and of the perception of their colleagues. M. Gabbott [36] quotes several psychological studies which show that non-verbal behaviour by the service provider affects service evaluation, because the quality of interaction between customer and service provider influences customers' perception of service quality. Al.M.Barnard [4] says that in services, a single employee may affect service efficiency and consequent customer satisfaction with the service. Kelly, Skinner[33] say that even customers own involvement and participation in service delivery affect customer satisfaction.

Every customer should be personally taken care of in order to maintain an existing customer base, as he/she is an invaluable asset and an investment in the future of the business because it costs far less to retain existing customers than win new ones. The key drivers of customer loyalty are positive staff attitude, honesty, integrity, and reliability, proactive advice and delivery of promise, consistent delivery of superior quality service, simplicity and ease of doing business, good after-sales service, and a fair and efficient complaints resolution policy. Customer interfacing personnel are the front line troops of any organisation and therefore need to be thoroughly trained with good customer relation's practice.

\section{Quality of service}

Attaining sustainable competitive advantage is practically difficult because the services cannot be easily copied and patented. Perceived service quality is the judgment of the customers of their overall experience of the service environment of an organization. The success in delivering quality service lays on understanding how customers arrive at this judgment. When an organization fails to study and understand the process of customer's judgment, it will loose a customer. Exactly, the competitive companies will target the lost customer. This will threaten the competitive position of the company in the market.

H. Emari, S. Iranzadeh and S. Bakhshayesh, [23] determined the dimensions of service quality in the banking industry of Iran and examined the European perspective (i.e., Gronroos's model) suggesting that service quality consists of three dimensions, technical, functional and image. The results from a banking service sample revealed that the overall service quality is influenced more by a consumer's perception of technical quality than functional quality. J. R. Salifu[53] stated that both customers and bankers in small part perceived a positive correlation between the antecedents of service performance gaps and service quality dimensions. M. Hossain, S.Leo, [27] have stated that in order to achieve higher levels of quality service in retail banking, banks should deliver higher levels of service quality and in the present context customers' perceptions are highest in the level of infrastructure facilities of the bank, followed by timing of the bank, and return on deposit. Owing to the increasing competition in retail banking, customer service is an important part and bank managers should be rethinking how to improve customer satisfaction with respect to service quality.

The personnel in the services sector have to prove that their services are customer-focused and that continuous process improvement is being delivered. C.-J.Liang, W.-HWang, [15] aim to test the relationship between perceived service quality satisfaction and the relationship intentions that is, whether or not consumers will consider building long-term relationships with service providers on the basis of a single instance of perceived service quality. They suggest that financial products with different product attributes need different kinds and levels of service and relationship investment and also suggest that there exists a positive relationship between service quality satisfaction and perceived relationship investment. The results of the survey analysis showed that only one driver - the financial driver - is significant to the advisors in keeping their clients satisfied.

The perishability of service also means that a service cannot be exactly repeated and it may result in dissatisfaction of the customers if their expectations are not met. Promsri, Chaiyaset[49] measured service quality by the banking customers' perceptions of service quality of service providers using five dimensions of the SERVQUAL (tangibles, reliability, responsiveness, assurance, and empathy). It was found that the empathy of service providers, an emotional intelligence factor, was a significant explanatory variable of customer retention. However, the relationship was inverse: the lower the empathic skills of service providers, the more favorable the behavioral intentions of customers to do business with the bank. Huang, Chen-Yu [28] has found by administering SERVQUAL model (Parasuraman, Zeithaml, and Berry [46]), that there are significant differences in service perceptions between customers and bankers.

Ch. A. Voss, A. V. Roth, E.D. Rosenzweig, K.Blackmon 
and R.B Chase [75] compare the influence of service quality on customer satisfaction in the United Kingdom and the United States and consider the moderating effect of systematic customer feedback and complaint processes. A.Jamal and A.Adelowore [3] demonstrate that self-employee congruence is an important antecedent of personal interaction, relationship and loyalty to employees each of which is in turn positively linked to customer satisfaction towards the service provider. Ch.Boshoff and M.Tait [16], stress the importance of frontline employees in service delivery. The internal marketing concept is based on the belief that a firm's internal market/employees can be motivated to strive for customer-consciousness, market orientation and sales mindedness through the application of accepted external approaches and principles. Although technology still dominates, human resources and how they are managed is receiving increased attention in gaining competitive advantage. Factors including individual training and project involvement, job characteristics, organizational structure, social support and employees' self-efficacy were expected to influence employees' extrarole behaviours.

To gain greater customer experience and satisfaction, right person should be identified, properly trained, supervised, motivated and providing conducive work environment with clear understanding of the rules of the organization. The high levels of internal service quality (good service between departments and divisions) lead to higher levels of employee satisfaction. The happier employees are, the more likely they are to stay and the better their productivity. These two factors combine to provide better levels of service to customers, creating higher levels of satisfaction and higher levels of loyalty.

\section{Customer complaints}

Customers are more knowledgeable, sophisticated, informed and assertive. They demand higher levels of customer service and more inclined to switch to a competitor. If a customer expects a certain level of service, and perceives the service reviewed to be higher, he is a satisfied client. If he perceives the same level as before, but expected higher, he is a disappointed and, accordingly, a dissatisfied client.

L. Makdessian, [35], states that angry customers were also more likely to complain and engage in third-party action, and were less likely to spread positive word-of-mouth and repurchase from the service firm. Gender of the customer and the service employee played only a minimum role in influencing the evaluative and behavioral outcomes. M.D. Richards and D.Hicks [40] state that the response chosen by the retailer, as well as the time and effort exerted by the consumer can influence consumer satisfaction / dissatisfaction (S/D) with the complaint resolution process. Results suggest that consumer S/D with the complaint resolution process has four critical dimensions. The two consumer input dimensions are consumer time and consumer effort expended in an attempt to resolve the problem. The two outcome dimensions are compensation received and attributed of the retailer's representative.

A service failure in an organization leads to complaint system. Any complaint from the customers will be taken care under service recovery system. This recovery system may or may not meet the expectations of the customers. If they are met, it results in customer satisfaction which increases the loyalty of the customers. If the expectations are not met, it will result in customer dissatisfaction which in turn forms as a service failure. T. D. Jones [31] says that Service Provider failures lead to reductions in service company commitment, service provider commitment, and some loyalty-related outcomes. This effect is reduced under conditions of high interpersonal commitment. Personal betrayals lead to reductions in all three targets of commitment which, in turn leads to reductions in loyalty-related outcomes. It is also proved that the outcomes of service failures are not necessarily most evident on loyalty-related outcomes; reduction in commitment levels after failed encounters is the likely consequence of these failures.E. Ph. Simpson [64] analysed the relationships between three variables namely, employee satisfaction, customer service quality, and customer satisfaction in a mid-sized retail bank.

The American Technical Research Programme (TRAP) [70] has found that a dissatisfied consumer will tell an average of nine to ten people about their experience and these, in turn, will tell others, warning them not to purchase products or services from the business in question. Day and Landon [21] state that the most common approach is to contact the service provider from whom they purchased the products and/or services. Day and Ash [20] state that dissatisfied consumers also switch the brands they buy or go to other service providers. Consumers may also resort to taking public action in order to resole their complaints. Schouten and van Raaij [61] reveal that if dissatisfied consumers are unable to secure a satisfactory response from the company, they may use third-party complaint handling agencies to seek redress. These three parties may include mediasponsored consumer advocates, Governmental consumer protection departments, and even solicitors. It would appear that the type of complaint behaviour exhibited by dissatisfied consumers is dependent on the nature and importance of the product or service purchased and on the perceived effort required and likely outcome resulting from such behaviour.

Singh [65] says that consumer complaint behaviour (CCB) represents a breakdown or weakness in the exchange process, an understanding of which is essential for rectification of the problem. An organization that is aware of and understands the CCB process has a much greater ability to reduce the possible occurrences of dissatisfaction that are not preventable. Reducing the number of dissatisfied customers and increasing the number of satisfied customers will invariably lead to an increase in sales, brand loyalty and positive word-of-mouth. 


\section{Conclusion}

In the present consumer economy, attracting and crucially keeping customers for long-term is a key challenge for any organization. The customer is at the center of all business activities and particularly, the banks have organized by positioning the staff to meet the needs of the customers in a highly customized and responsive manner. The ultimate, in customer satisfaction, is giving customers exactly what they want. The customers are the most valuable asset of any organization. An organization's success depends on how many customers it has, how much they buy, and how often they buy. Customers that are satisfied will increase in number, buy more, and contact the bank frequently for various reasons. Attraction, retention and enhancement of the customer relationship are essential to maintain, delighted and committed customers, who form the basis for the sustainable competitive position of the bank. Impact of service encounters, role of intermediaries, quality of service, waiting time and customer complaints are considered essential for an organization to find out the gaps in the perceptions and expectations of the customers. The organizations should continuously monitor and evaluate the services offered by them to the customers and they should keep themselves ahead of their own competitors. This study can also be extended to tourism and hospitality, insurance companies, hospitals, transport corporations, railways, airlines, telecommunications libraries and other service sectors to assess the degree of quality of service offered by them. The results obtained from the study will help the organizations to take necessary actions to improve the service quality and achieve the customer satisfaction.

\section{References}

1 Gaudet A P, Customer relationship marketing and effects of demographics and technology on customer satisfaction and loyalty in financial services, Old Dominion University, United States - Virginia, 2004.

2 Pruyn A, Smidts A, Effects of waiting on the satisfaction with the service: Beyond objective time measures, Rotterdam School of Management. Erasmus University, Rotterdam, Netherlands, 1998.

3 Jamal A, Adelowore A, Customer-employee relationship: The role of selfemployee congruence, European Journal of Marketing 42 (2008), no. 11/12, 1316-1345, DOI 10.1108/03090560810903691.

4 Barnard A M, Feedback Seeking in Customer Service Relationships, The Department of Psychology, Louisiana State University, 2002.

5 Diaz A B C, Ruiz F J M, The Consumer's Reaction to Delays in Service, International Journal of Service Industry Management 13 (2002), no. 2, 118140, DOI 10.1108/09564230210425331.

6 Rafaeli A, Barron G, Haber K, The effects of Queue Structure on Attitudes, Journal of Service Research 5 (2002), 125-39, DOI $10.1177 / 109467002237492$.

7 Allred A T, Addams H L, Service quality at banks and credit unions: What do their customers say?, Managing Service Quality 10 (2000), no. 1, 52-60, DOI 10.1108/09604520010307049.

8 Bandura A, Social Foundations of Thought and Action; a Social Cognitive Theory, Prentice Hall, Englewood Cliffs, NJ, 1986.

9 Bargal, Sharma, Role of Service Marketing in Banking Sector, The Icfai Journal of Services Marketing VI (2008), no. 1, 62.

10 Dellaert B G C, Kahn E B, How tolerable is delay? Consumers' evalu- ations of internet web sites after waiting, Journal of Interactive Marketing 13 (1999), 41-54, DOI 10.1002/(SICI)1520-6653(199924)13:1<41::AIDDIR4>3.0.CO;2-S. Winter.

11 Berry L L, Relationship Marketing, Emerging Perspectives on Services Marketing (Berry L L, Shostack G L, Upah G D, eds.), American Marketing Association, Chicago, 1983, pp. 25-28.

12 Brown S W, Swartz T A, A gap analysis of professional service quality, Journal of Marketing 53 (1989), no. 4, 92-98, DOI 10.2307/1251416.

13 Byun S., The value of technology in service encounters: Exploring consumer perceptions of biometric access at automatic teller machines, Purdue University, United States, Nov 2007.

14 Chebat J, Impact of waiting attribution and consumer's mood on perceived quality, Journal of Business Research 34 (1995), no. 3, 191-196, DOI 10.1016/0148-2963(95)98346-4.

15 Liang C.-J, Wang W-H, The behavioural sequence of the financial services industry in Taiwan: Service quality, relationship quality and behavioural loyalty, Service Industries Journal 26 (2006), no. 2, 119-145, DOI 10.1080/02642060500369131.

16 Boshoff Ch, Tait M, Quality perceptions in the financial services sector: The potential impact of internal marketing, International Journal of service industry management 7 (1996), no. 5, 5-31, DOI 10.1108/09564239610149939.

17 Cowgill M. A, Drivers of client satisfaction: A study of financial advisors and client service techniques, Argosy University/Sarasota, United States Florida, 2002.

18 Czepiel J A, Solomon R, Bitner MJ, Surprenant CF, The Service Encounter: Managing employee/customer interaction in service business, 1985. Lexington, Mass: Lexington Books.

19 Dawes J, Rowley Jennifer, The waiting experience: towards service quality in the leisure industry, International Journal of Contemporary Hospitality Management 8 (1996), no. 1, 16-21, DOI 10.1108/09596119610108608.

20 Day R L, Ash S B, Consumer response to dissatisfaction with durable products, Advances in Consumer Research 6 (1979), 438-444.

21 Day R L, Landon E L, Towards a theory of consumer complaining behavior in consumer and industrial buying behavior, Arch woodside, Amsterdam, North Holland (AG Woodside J. S., ed.), North Holland Publishing Company Press, 1977, pp. 425-432.

22 Dilip Soman, Rongrong Zhou, Waiting for service: Affective responses, satisfaction and decision making of consumers waiting in queues, Advances in Consumer Research 29 (2002), no. 1, 412-419.

23 Emari $\mathbf{H}$, Iranzadeh S, Bakhshayesh S, Determining the dimensions of service quality in banking industry: Examining the Gronrooss model in Iran, Trends Applied Sciences Research 6 (2011), 57-64, DOI 10.3923/tasr.2011.57.64.

24 Fisk RP, Brown SW, Bitner MJ, Tracking the Evolution of the Services Marketing Literature, Journal of Retailing 69 (1993), no. 1, 61-104, DOI 10.1016/S0022-4359(05)80004-1.

25 Gail T, Scott L, Waiting time delays and customer satisfaction in supermarkets, Journal of Services Marketing 9 (1995), no. 5, 20-29, DOI 10.1108/08876049510100281.

26 Gummesson E, Total Relationship Marketing: Marketing Management, Relationship Strategy and CRM Approaches for the Network Economy, Oxford: Butterworth-Heinemann, 2002.

27 Hossain M, Leo S, Customer perception on service quality in retail banking in Middle East: the case of Qatar, International Journal of Islamic and Middle Eastern Finance and Management 2 (2009), no. 4, 338-350, DOI 10.1108/17538390911006386.

28 Huang C.-Y., The effect of service performance on service quality: An investigation of the banking industry in Taiwan, Nova Southeastern University, United States, June 2004.

29 Heskett J L, Beyond customer loyalty, Managing Service Quality MCB UP Ltd 12 (2002), no. 6, 355- 57, DOI 10.1108/09604520210451830. 
30 Chernow J R, Measuring the values of Travel Time Savings, Journal of Consumer Research 7 (1981), 360-371, DOI 10.1086/208826.

31 Jones T., Personal, professional and service company commitments in service relationships, , Queen's University at Kingston, Canada, 2003.

32 Kelley S W, Managing Service Quality: The Organizational Socialization of the Service Employee and Customer, University of Kentucky, United States - Kentucky, 1987.

33 Kelly SW, Skinner S J, Organisational socialization of service customers, Journal of Business Research 25 (1982), 197-214, DOI 10.1016/01482963(92)90029-B.

34 Szabó K, Customer authentication, as a matter of risk in financial services, Social and Management Sciences, Periodica polytechnica 11 (2003), no. 1, 13-26.

35 Makdessian L., Consumers' reactions to service failures: The intervening roles of anger and gender, Concordia University, Canada, Dec 2004.

36 Gabbott M, Hogg G, An empirical investigation of the impact of non-verbal communication on service evaluation, European Journal of Marketing 34 (2000), no. 3/4, 384-398, DOI 10.1108/03090560010311911.

37 Davis M M, Janelle Heineke, How disconfirmation, perception and actual waiting times impact customer satisfaction, International Journal of Service Industry Management 9 (1998), no. 1, 64-73, DOI 10.1108/09564239810199950.

38 Mary Jo Bitner, Hubbert AR, Encounter Satisfaction Versus Overall Satisfaction Versus Quality (1994), 72-94. Rust RT, Oliver RL. (Ed.) Service Quality: New Directions in Theory and Practice, Thousand Oaks, CA, Sage Publications.

39 Mary Jo Bitner, Servicescapes: The Impact of Physical Surroundings on Customers and Employees, Journal of Marketing 56 (1992), 57-71.

40 Richards M D, Dee Dee Hicks, The HASSLE Scale: Measuring Consumer Satisfaction/Dissatisfaction with the Complaint Resolution Process, Journal of Customer Service in Marketing and Management (1997), no. 4, 61-73.

41 Hui M K, Mrugank V Thakor, Ravi Gill, The effect of delay type and service stage on consumers' reactions to waiting, Journal of Consumer Research 24 (1998), no. 4, 469-480, DOI 10.1086/209522.

42 Hui M K, Tse D K, What to Tell Customers in Waits of Different Lengths: An Integrative Model of Service Evaluation, Journal of Marketing 80 (1996), no. 2, 81-90.

43 Kallo N, Koltai T, A review of management issues related to express line systems, Social and Management Sciences Periodica Polytechnica 16 (2008), no. 1, 21-32, DOI 10.3311/pp.so.2008-1.03.

44 Odekerken-Schroder G, The Role of the Buyer in Affecting Buyer-Seller Relationships. Empirical Studies in a Retail Context, Maastricht University, Maastricht, 1999.

45 Oliver RL, Satisfaction, a Behavioural Perspective on the Consumer, Vol. 13, New York: McGraw-Hill, 1997.

46 Parasuraman A, ZeithamI V A, Berry L L, Delivering Service Quality: Balancing Customer Perceptions and Expectations, The Free Press, New York, NY, 1990.

47 Parasuraman A, Superior Customer Service and Marketing Excellence: Two Sides of the Same Success Coin, Vikalpa:, The Journal for Decision Makers 25 (2000), no. 3, 3-13.

48 Parkington J, Schneider B, Some correlates of experienced job stress: a boundary role study, Academy of Management Journal 22 (1979), no. 2, 270-81, DOI 10.2307/255589.

49 Promsri, Chaiyaset, Perceived service quality, emphasizing empathy of service providers and retention of customers in a commercial bank in Bangkok Thailand, Lynn University, United States, Nov 2005.

50 Larson R C, Perspectives on Queues: Social justice and the Psychology of Queueing, Operations Research 35 (1987), no. 6, 895-905, DOI 10.1287/opre.35.6.895.
51 Dwyer F R, Schurr H Paul, Sejo Oh, Developing Buyer-Seller Relationships, Journal of Marketing 51 (1987), 11-27, DOI 10.2307/1251126.

52 Morgan R M, Hunt S D, The Commitment-Trust Theory of Relationship Marketing, Journal of Marketing 58 (1994), 20-38, DOI 10.2307/1252308.

53 Salifu Justice R, The nexus of service performance and service quality: A study of the Ghanaian retail banking industry, Capella University, United States, Nov 2010.

54 Sasser WE, Olsen J, Wyckoff DD, Management of Service Operations: Text, Cases and Readings, Allyn and Bacon, New York, 1979.

55 Schijns J, Loyalty and Customer Satisfaction: two in one?, Bedrijfskunde 74 (2002), no. 1, 57-65.

56 Schijns J, Measuring and Managing Relationships between Customers and Organizations, Maastricht University, Maastricht, 1999. doctoral dissertation.

57 Schneider B, Bowen D, The service organization: human resources management is crucial, Organizational Dynamics (1993), no. 4, 39-52.

58 Schneider B, Bowen DE, Employee and customer perceptions of service in banks: Replication and extension, Journal of Applied Psychology 70 (1985), no. 3, 423-433, DOI 10.1037//0021-9010.70.3.423.

59 Schneider B, Parkington JJ, Buxton VM, Employee and customer perceptions of service in banks, Administrative Science Quarterly 25 (1980), no. 2, 252-267, DOI 10.2307/2392454.

60 Schneider B, The perception of organizational climate: The customer's view, Journal of Applied Psychology 57 (1973), no. 3, 248-256, DOI 10.1037/h0034724.

61 Schouten V, van Raaij W, Consumer problems and satisfaction in a retail setting, Consumer Satisfaction/Dissatisfaction \& Complaint Behavior 3 (1990), 56-60.

62 Shankar V, Smith A K, Rangaswamy A, Customer Satisfaction and Loyalty in Online and Offline Environments, eBusiness Research Center Working Paper Penn State University, October, 2000.

63 Shea C M, Howell JM, Organizational antecedents to the successful implementation of total quality management: a social cognitive perspective, Journal of Quality Management 3 (1998), no. 1, 3-25, DOI 10.1016/S10848568(99)80101-1.

64 Simpson E P., Examining employee satisfaction, customer service and customer satisfaction in a retail banking organization, University of North Texas, Oct 2006.

65 Singh J, Consumer Complaint Intentions and Behavior: Definitional and Taxonomical Issues, Journal of Marketing 52 (1988), 93-107, DOI 10.2307/1251688.

66 Soteriou A. C, Searching for the Value of Quality in Financial Services, service quality, 2000. Working Papers - Financial Institutions Center at The Wharton School.

67 Spirou P. A., Factors affecting service quality through client-provider interactions, Nova Southeastern University, United States - Florida, 2000.

68 Surprenant C F, Solomon M, Predictability and personalization in the service encounter, Journal of Marketing 51 (1987), 86-96, DOI $10.2307 / 1251131$.

69 Jonás T, Kövesi J, Reliability based customer satisfaction evaluation, Soc. and Manag. Sci. Periodica Polytechnica 18 (2010), no. 1, 3-9, DOI 10.3311/pp.so.2010-1.01.

70 Technical Assistance Research Program, Consumer Complaint Handling in America, Washington, DC: Department of Consumer Affairs, 1986. An Update Study.

71 Toelle S., The linkages among service quality attributes, customer value, customer satisfaction, and customer loyalty in Indonesian retail banking settings, Nova Southeastern University, United States, Aug 2006.

72 Tu R., Service quality and expectation: The critical impact of emotions and service experience on customer satisfaction, The University of North Carolina at Chapel Hill, United States - North Carolina, 2004. 
73 ZeithamI V A, Parasuraman A, Malhotra A, Service quality delivery through Web sites: A critical review of extant knowledge, Academy of Marketing Science 30 (2002), no. 4, 362-375, DOI 10.1177/009207002236911.

74 Vimi J, Mohd K K, Determinants of performance in retail banking: perspectives of customer satisfaction and relationship marketing, Singapore Management Review, December, 2008.

75 Voss C. A, Roth A V, Rosenzweig E D, Blackmon K, Chase R B, A tale of two countries' conservatism, service quality and feedback on customer satisfaction, Journal of Service Research 6 (2004), no. 3, 212-230, DOI 10.1177/1094670503260120.

76 Young S. D., The effects of customer loyalty on profitability, Saint Louis University, United States - Missouri, 2000. 